\title{
Greenhouse Gas Emissions from Wastewater Treatment System
}

\author{
Rohini Prasad Devkota \\ Central Department of Environmental Science, Tribhuvan University, Kathmandu, Nepal \\ Corresponding e-mail: rohinidevkota@yahoo.com
}

\begin{abstract}
Besides its great potential in controlling water pollution from different sources, waste water treatment system generates significant amount of greenhouse gases. Hence, reducing the emission of greenhouse gases from the wastewater treatment plants is the major concern. The correct understanding and estimation of the greenhouse gases emitted from different points of the plan is essential to tackle this challenge. This research has attempted to evaluate and quantify the greenhouse gases, mainly methane and nitrous oxide, emissions from the wastewater treatment system under varying conditions of temperature and oxygen.

The sludge samples were collected from the septic tank, aeration tank, denitrification tank and digestion tank to examine the emission of greenhouse gases from the samples with and without nutrients and volatile fatty acids(VFA). To examine the effect of temperatures on the emission of greenhouse gases, experiments were designed under different temperatures by keeping reactors at $4^{\circ} \mathrm{C}, 20^{\circ} \mathrm{C}, 25^{\circ} \mathrm{C}, 30^{\circ} \mathrm{C}, 37^{\circ} \mathrm{C}$ and $50^{\circ} \mathrm{C}$. Similarly, experiments were carried out at $37^{\circ} \mathrm{C}$ under different amount of oxygen supply $(0,0.1,0.4,1.0$ and $2.0 \mathrm{mg} / \mathrm{L}$ ) to examine the role of oxygen in greenhouse gases emission.

Experimental results showed that the rate of emission of $\mathrm{CH}_{4}$ gas from the sludge sample was enhanced with the presence of glucose, nutrients and VFA. Rate of $\mathrm{CH}_{4}$ production was well correlated with sludge temperature. It was similar for all sludge samples taken from different points of the treatment plant. Rate of production was found highest for digestion sludge and least fir septic sludge. $\mathrm{CH}_{4}$ production was started earlier and found fastest from the digestion sludge. An inverse relationship was found between the rate of $\mathrm{CH}_{4}$ emission and the amounts of oxygen present in the sludge sample. However, $\mathrm{N}_{2} \mathrm{O}$ emission was not detected at all.
\end{abstract}

Keywords: Methane, Anaerobic, Temperature, Nutrients, Wastewater, Sludge

\section{Introduction}

Water scarcity and water pollution are serious environmental problems in many the urban areas. The rapidly increasing population in the urban areas of developing countries has added to the scarcity of water. The inappropriate management of domestic sewage and industrial discharge has exacerbated the water pollution. This situation has necessitated water treatment system and different techniques are in practice for the treatment of waste water. These systems are, now, proven to be effective means not only in meeting the demand of water for different purposes, but also in restoring the degraded aquatic ecosystem and environment.

Wide ranges of wastewater treatment systems are available to maintain the chemical, physical, and biological integrity of water. Physical, chemical, and biological units have been developed and are applied for the treatment of wastewater. The wastewater treatment systems are not totally environmentally friendly as they generate various greenhouse gases (GHGs). GHGs like $\mathrm{CO}_{2}, \mathrm{CH}_{4}$ and $\mathrm{N}_{2} \mathrm{O}$ are released from different components of the treatment system. There has been gradual increase in the trend of these $\mathrm{CH}_{4}$ and $\mathrm{N}_{2} \mathrm{O}$ gases emission from 1998 to 2004 (Figure1). 


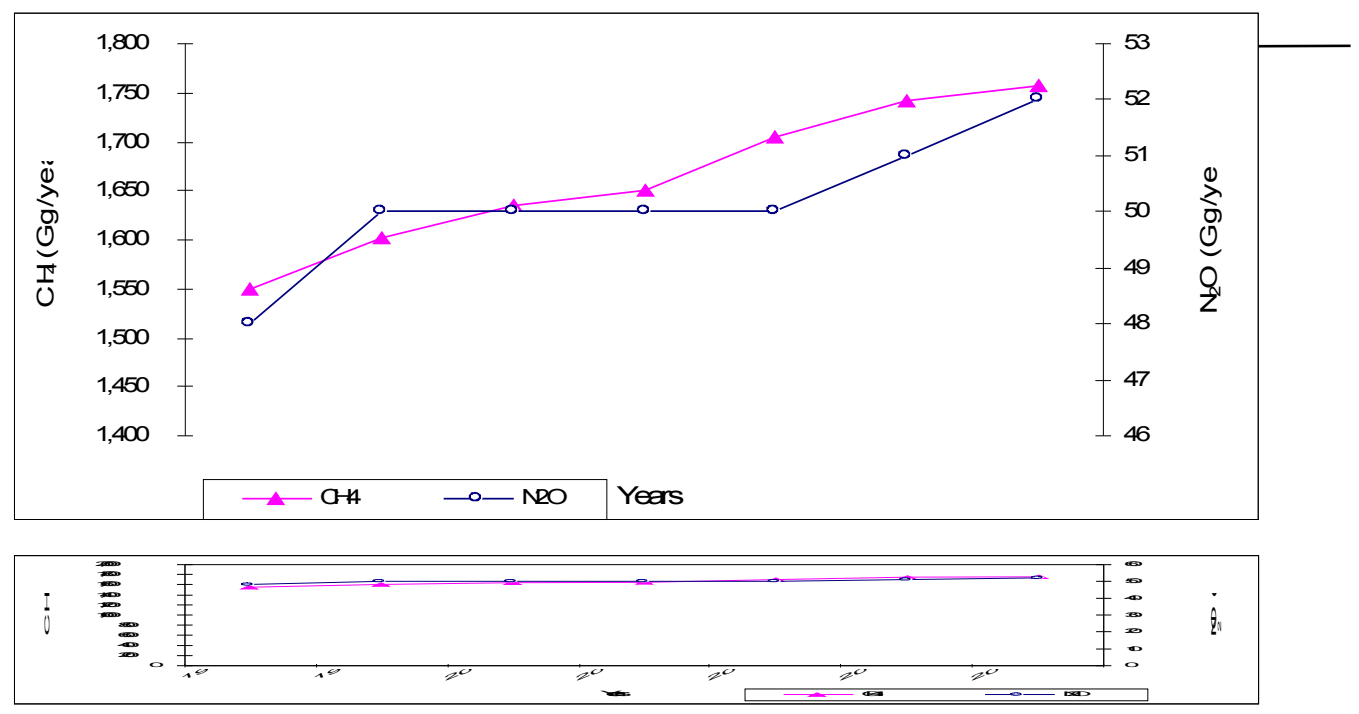

Figure 1: Greenhouse gas emissions from waste and wastewater treatment systems.

Source: IPCC annual report (2005)

The study has focused on evaluating and quantifying greenhouse gases emission from the wastewater treatment sludge. The aim of study is to evaluate and quantify the GHG emissions from it. This study mainly focuses on the role of nutrients $\left(\mathrm{NO}_{3}^{-}, \mathrm{NH}_{4}^{+}\right)$, glucose and VFA, temperature and oxygen on the GHG emissions from wastewater treatment sludge.

\section{Methods and Materials}

Sludge samples were collected from septic tank, aeration tank, denitrification tank and digestion tank of the wastewater treatment system which is shown schematically in Fig 2. 60 Sludge samples of $500 \mathrm{ml}$ were taken from 4 and glucose, $\mathrm{NH}_{4}{ }^{+}, \mathrm{NO}_{3}{ }^{-}$and volatile fatty acids (VFA) were added to examine their effect in the emission of greenhouse gases. Experiments were carried out under different sets of temperatures and oxygen levels. The effects of temperature and oxygen in the emission of GHGs from the wastewater sludge can be done only in those places where we can control these parameters. The quantity of methane and nitrous oxide emitted from these sludge samples were measured by using Gas Chromatograph (GC) with thermal conductivity detector. 


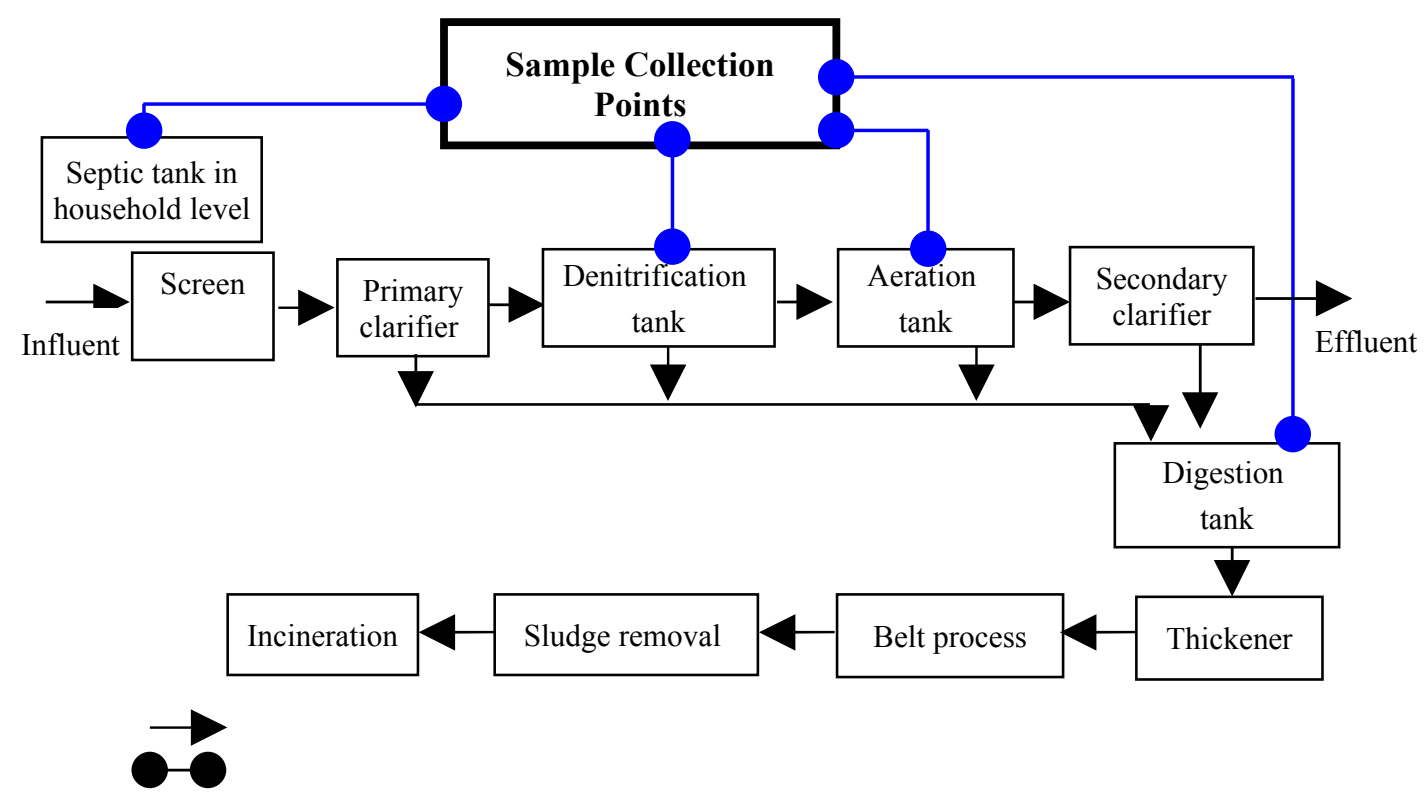

Legends: Flow process

Sample collection points

Figure 2: Block diagram of the system indicating the sampling points

\section{Results and Discussion}

\subsection{Effect of Temperature on GHGs Emission from Denitrification Sludge}

The measured rates of produced $\mathrm{CH}_{4}$ methane from the denitrification tank with and without VFA are presented in Table 1 . The P- value obtained from hypothesis testing at $95 \%$ confidential level and $\mathrm{R}^{2}$ obtained from regression analysis are also given in Table 1. The emission rate of $\mathrm{CH}_{4}$ from denitrification sludge sample was found high in the sludge temperature increase and the effect of VFA contain at $20^{\circ} \mathrm{C}$. In this temperature the ratio of the rate of emission of $\mathrm{CH}_{4}$ from the sludge sample that contained VFA came to be almost $150 \%$ more than that from the sludge alone. In other temperatures, this ratio is almost equal to 1. It can be seen in Fig. 3 in which methane emission rate was plotted against temperature. The optimum temperature for $\mathrm{CH}_{4}$ emission from denitrification sludge was above $37{ }^{\circ} \mathrm{C}$. Both rate of $\mathrm{CH}_{4}$ emission and $\mathrm{CH}_{4}$ production (from dry weight) increases with increase in temperature of denitrification sludge.

Table 1: Methane production rates and dry weight of denitrification sludge with and without VFA at different temperatures

\begin{tabular}{|c|l|c|c|c|c|}
\hline Temperature & Activities & $\begin{array}{c}\mathrm{CH}_{4} \text { Emission } \\
(\mathrm{mg} / \mathrm{L} / \mathrm{d})\end{array}$ & $\mathrm{P}$ - value & $\mathrm{R}^{2}$ & $\begin{array}{c}\mathrm{CH}_{4} \text { production } \\
\text { from dry weight } \\
\left(\mathrm{mg} \mathrm{CH}_{4} / \mathrm{gdw}\right. \\
\text { sludge })\end{array}$ \\
\hline $4^{\circ} \mathrm{C}$ & Sludge & 0 & - & - & - \\
\cline { 2 - 6 } & Sludge + VFA & 0 & - & - & - \\
\hline $20^{\circ} \mathrm{C}$ & Sludge & 6.0 & 0.000000126 & 0.98 & 65 \\
\hline
\end{tabular}




\begin{tabular}{|c|l|c|c|c|c|}
\hline \multirow{2}{*}{$25^{\circ} \mathrm{C}$} & & & & & \\
\cline { 2 - 6 } & Sludge + VFA & 6.7 & 0.00073 & 0.92 & 108 \\
\cline { 2 - 6 } & Sludge & 9.4 & 0.034 & 0.89 & 136 \\
\hline \multirow{2}{*}{$30^{\circ} \mathrm{C}$} & Sludge + VFA & 9.7 & 0.290 & 0.92 & 150 \\
\cline { 2 - 6 } & Sludge & 10.4 & 0.000147 & 0.94 & 144 \\
\cline { 2 - 6 } $37^{\circ} \mathrm{C}$ & Sludge + VFA & 11.6 & 0.89 & 0.96 & 183 \\
\cline { 2 - 6 } & Sludge & 11.7 & 0.0127 & 0.87 & 87 \\
\cline { 2 - 6 } $50^{\circ} \mathrm{C}$ & Sludge + VFA & 12.2 & 0.39 & 0.87 & 86 \\
\cline { 2 - 6 } & Sludge & 12.2 & 0.124 & 0.89 & 141 \\
\cline { 2 - 6 } & Sludge + VFA & 12.1 & 0.033105 & 0.75 & 177 \\
\hline
\end{tabular}

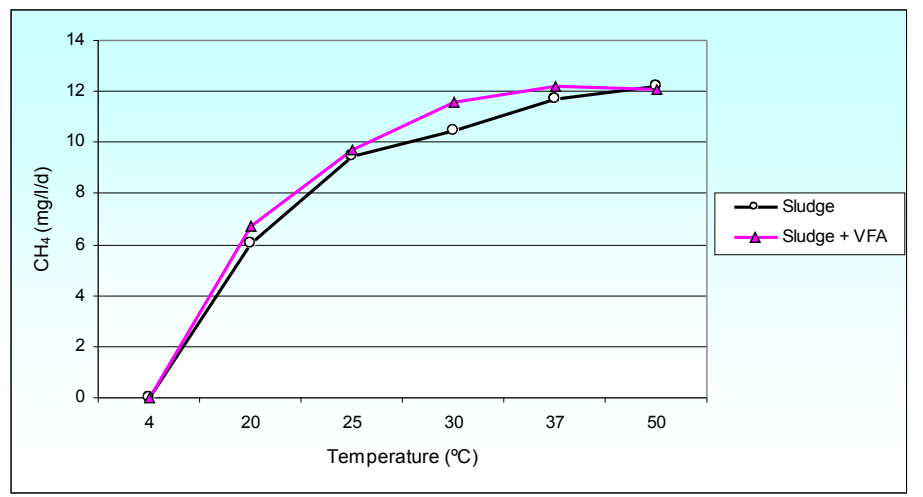

Figure 3: Methane production rate from the denitrification sludge at different temperatures

In all the experiments $\mathrm{CH}_{4}$ emissions took place from sludge samples taken from denitrification tank while $\mathrm{N}_{2} \mathrm{O}$ emission could not be traced at all. There is a positive relationship between $\mathrm{CH}_{4}$ emission and temperature. The emission of $\mathrm{CH}_{4}$ gas from the sludge is slow at lower temperature and becomes faster with the increase in temperature. It should be due to slower microbial activities at lower temperatures. It is due to the fact that at higher temperature, biological activities that affect $\mathrm{CH}_{4}$ emission increase (Zhu et al., 2006). This finding is in conformity with that of (Lin's,2001) conclusion i.e. temperature affects chemical reaction and biological activities. (Gupta et al, 2006) stated that there was a significant correlation of solid manure with respect to ambient temperature and consequent $\mathrm{CH}_{4}$ emission. In this study also similar results were obtained regarding the effect of temperature on GHGs emission.

In similar, $\mathrm{CH}_{4}$ was found emitted but the $\mathrm{N}_{2} \mathrm{O}$ emission could not be detected as in those experiments without VFA. The results show that, the rate of $\mathrm{CH}_{4}$ emission increases from the combination of sludge +VFA with temperature, although there was a slight decrease in the emission at $50{ }^{\circ} \mathrm{C}$ than that of $37{ }^{\circ} \mathrm{C}$. The total amounts of $\mathrm{CH}_{4}$ emitted at the end of the experiment for the setup at different temperature were equal. The rate of $\mathrm{CH}_{4}$ emissions from sludge was optimum from $30^{\circ} \mathrm{C}$ and $50^{\circ} \mathrm{C}$. This finding is in conformity with Zinder et al. (1984) conclusion optimum temperature for mesophiles bacteria is $30-40^{\circ} \mathrm{C}$. 


\subsection{Greenhouse Gas Emission from Different Sludge Samples at $20^{\circ} \mathrm{C}$}

Two sludge samples were taken from each of the Aeration tank, Digestion tank, Denitrification tank and Septic tank sample points at $20^{\circ} \mathrm{C}$. The coefficient of regression is more than $90 \%$ in every case except 'sludge +VFA' combination in which it assumes a value slightly lower than $90 \%$. The tests carried out at $95 \%$ confidential level also showed that there is a significant relationship between $\mathrm{CH}_{4}$ production and time in days. The rate of $\mathrm{CH}_{4}$ production is higher from the sludge that contains nutrients than the sludge without nutrients (Figures 4, 5, 6, and 7)..

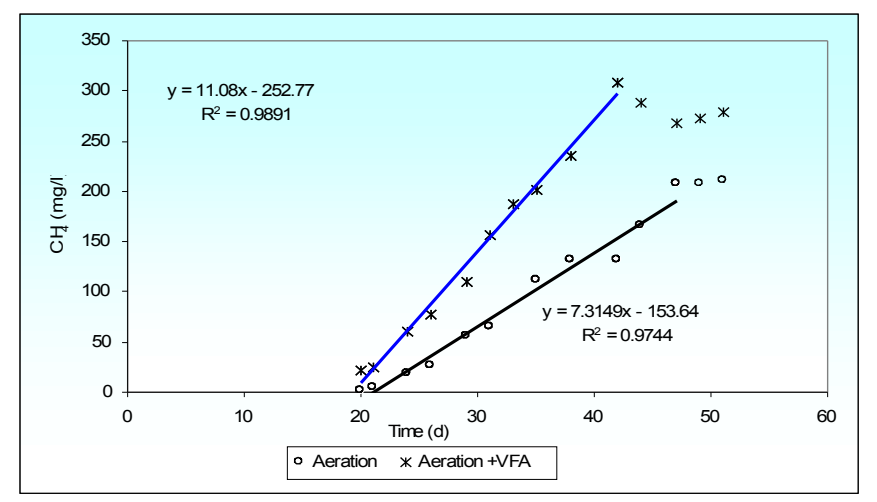

Figure 4: Effect of VFA on $\mathrm{CH}_{4}$ production from aeration sludge at $20^{\circ} \mathrm{C}$

The emission rate of $\mathrm{CH}_{4}$ of the sludge sample taken form aeration tank came to be $7.3 \mathrm{mg} / \mathrm{L}$ per day $\left(\mathrm{R}^{2}=0.98\right.$, P- value $\left.=0.000192\right)$ whereas it came to be $11.0 \mathrm{mg} / \mathrm{l}$ per day when the sludge containing VFA $\left(\mathrm{R}^{2}=0.95\right.$, $\mathrm{P}$ - value $\left.=0.000029\right)$. The $\mathrm{CH}_{4}$ production was found to be $76 \mathrm{mg}$ per $\mathrm{g} \mathrm{dw}$ for sludge alone while this value came to be $118 \mathrm{mg}$ per $\mathrm{g} \mathrm{dw}$ sludge for the sludge containing VFA. Not only the rate of production but also the amount of $\mathrm{CH}_{4}$ production was found high when there was nutrient in the sludge. In the same way, it was found that production of $\mathrm{CH}_{4}$ started from sludge as well as 'sludge $+\mathrm{VFA}$ ' samples taken from Aeration tank almost at same days (after 20 days) and continued till 48 days, after which production was almost stabilized.

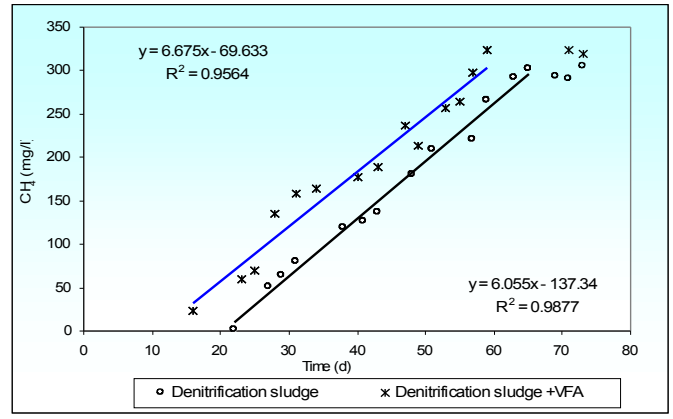

Figure 5: Effect of VFA on methane production from denitrification sludge at $20^{\circ} \mathrm{C}$ 
Similarly the emission rate of $\mathrm{CH}_{4}$ of the sludge sample taken form denitrification tank came to be $6.3 \mathrm{mg} / \mathrm{L}$ per day and $\left(\mathrm{R}^{2}=0.98, \mathrm{P}-\right.$ value $\left.=0.0000126\right)$ whereas it came to be $6.6 \mathrm{mg} / \mathrm{L}$ per day when the sludge contains VFA $\left(\mathrm{R}^{2}=0.95, \mathrm{P}\right.$ - value $\left.=0.00073\right)$. The methane production from the samples taken from Denitrification tank was found to be $65 \mathrm{mg}$ per $\mathrm{g}$ dw for sludge alone while this value came to be $108 \mathrm{mg}$ per $\mathrm{g}$ dw sludge for the sludge containing VFA. In this case the rate of production was found somewhat comparable in both cases but the amount of $\mathrm{CH}_{4}$ production were found higher when there was nutrient in the sludge. Likewise, $\mathrm{CH}_{4}$ production started from denitrification sludge and the combination of 'denitrification sludge + VFA' samples in different days i.e. $\mathrm{CH}_{4}$ was emitted from the sludge sample after 20 days while emission took place after 14 days from the start of the experiment when there was VFA in the sludge. The emission of $\mathrm{CH}_{4}$ continued up to 48 days and 63 days for "sludge sample" and "sludge + VFA sample" respectively.

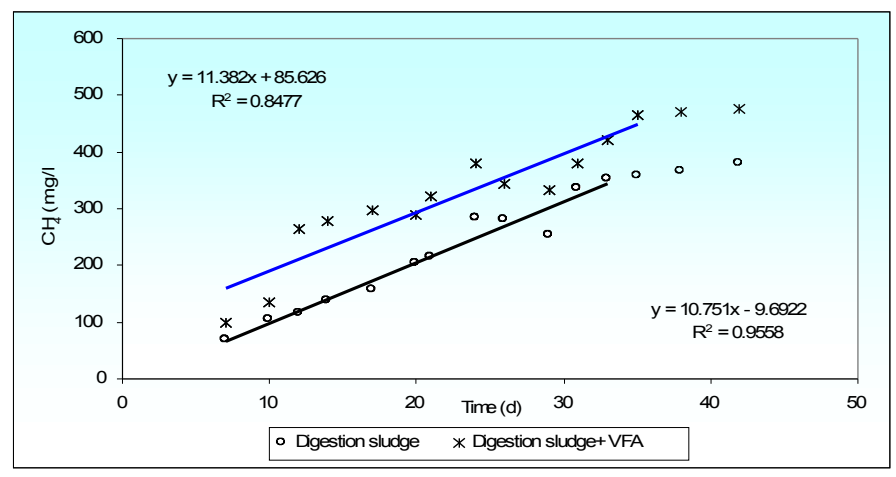

Figure 6: Effect of VFA on methane production from digestion sludge at $20^{\circ} \mathrm{C}$

The emission rate of $\mathrm{CH}_{4}$ of the sludge sample taken form digestion tank came to be $10.7 \mathrm{mg} / \mathrm{L}$ per day and $\left(\mathrm{R}^{2}=0.95, \mathrm{P}\right.$ - value $\left.=0.0412\right)$ whereas it came to be $11.3 \mathrm{mg} / \mathrm{L}$ per day, when the sludge contains VFA $\left(\mathrm{R}^{2}=0.84\right.$, $\mathrm{P}$ - value $\left.=0.001\right)$. The $\mathrm{CH}_{4}$ production from the samples was found to be $13 \mathrm{mg}$ per $\mathrm{g} \mathrm{dw}$ for sludge alone while this value came to be $17 \mathrm{mg}$ per $\mathrm{g}$ dw sludge for the sludge containing VFA. In this case the amount of $\mathrm{CH}_{4}$ production was found low in both cases. In the same way, $\mathrm{CH}_{4}$ production occurred from both the sludge and "sludge + VFA" samples of digestion tank after 7 days and continued up to 46 days. After 46 days the production became almost nil (zero).

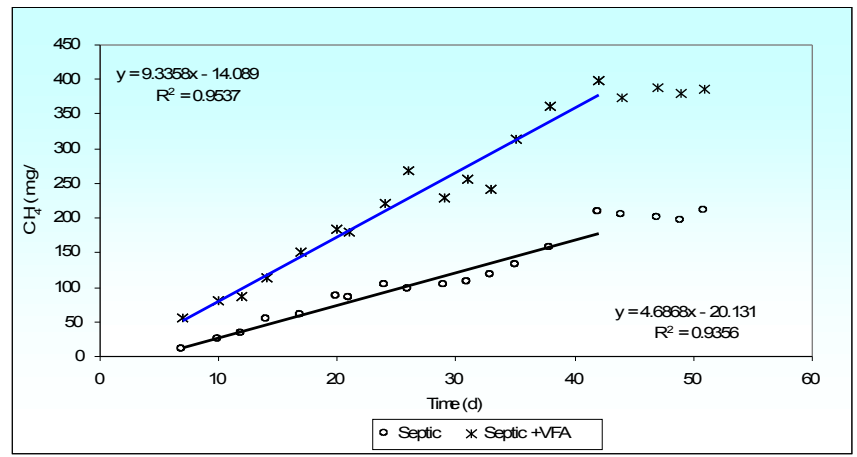

Figure 7: Effect of VFA on methane production from septic sludge at $20^{\circ} \mathrm{C}$ 
Likewise, the emission rate of $\mathrm{CH}_{4}$ of the sludge sample taken form septic tank came to be 4.7 $\mathrm{mg} / \mathrm{L}$ per day $\left(\mathrm{R}^{2}=0.93\right.$, P- value $\left.=0.640\right)$. This value came to be $9.3 \mathrm{mg} / \mathrm{L}$ per day when the sludge contains VFA $\left(\mathrm{R}^{2}=0.95\right.$, $\mathrm{P}$ - value $\left.=0.360\right)$. The $\mathrm{CH}_{4}$ production was found to be $4 \mathrm{mg}$ per $\mathrm{g} \mathrm{dw}$ for sludge alone while this value came to be $6 \mathrm{mg}$ per $\mathrm{g}$ dw sludge for the sludge containing VFA. The rate of methane production was found higher when there was nutrient in the sludge. Similarly, $\mathrm{CH}_{4}$ production had started from the sludge of the Septic tank with and without VFA almost at the same days (after 20 days) and continued up to 46 days. Emission of gases ceased after 46 days. Start of methane production was found fastest from the digestion sludge. Rate of production after the start of emission was found highest for digestion sludge and least for septic sludge. The rates of emission of $\mathrm{CH}_{4}$ from different sludge and dry weight sludge at VFA combination are given in Table 2.

Table 2: GHGs emission and dry weight of different sludge sample points.

\begin{tabular}{|l|c|c|c|c|}
\hline \multicolumn{1}{|c|}{ Activities } & $\begin{array}{c}\mathrm{CH} 4 \text { Emission } \\
(\mathrm{mg} / \mathrm{L} / \mathrm{d})\end{array}$ & $\mathrm{P}$ - value & $\mathrm{R}^{2}$ & $\begin{array}{c}\mathrm{CH}_{4} \text { production from } \\
\text { dry weight } \\
\left(\mathrm{mgCH}_{4} / \mathrm{gdw} \text { sludge }\right)\end{array}$ \\
\hline Aeration sludge & 7.3 & 0.000192 & 0.97 & 76 \\
\hline Aeration sludge + VFA & 11.0 & 0.000029 & 0.98 & 118 \\
\hline Denitrification sludge & 6.0 & 0.0000126 & 0.98 & 65 \\
\hline Denitrification sludge + VFA & 6.6 & 0.00073 & 0.95 & 108 \\
\hline Digestion sludge & 10.7 & 0.640 & 0.96 & 12 \\
\hline Digestion sludge + VFA & 11.3 & 0.001 & 0.89 & 17 \\
\hline Septic sludge & 4.6 & 0.0412 & 0.93 & 4 \\
\hline Septic sludge + VFA & 9.3 & 0.360 & 0.95 & 6 \\
\hline
\end{tabular}

The optimum temperature, presence of acetic acid - hydrogen, and anaerobic conditions favour methanogenic process for methane production (Chen, et al, 2006). Aeration and denitrification sludge are exposed to atmospheric air during the wastewater treatment process. The concentrations of organic matter in the sludge are lower compared to digestion and septic sludge. Also, digestion and septic sludge have anaerobic condition favouring for more methane production. However, septic sludge sample was used with longer storage time. This may be the reason for less significant methane production rate.

Nitrification and denitrification are $\mathrm{pH}$ sensitive and their rates decline significantly at $\mathrm{pH}$ values below 6.8 and optimal in the range of 7.5-8.0 (Metcalf and Eddy et al., 2002). However, the general trend is that as the $\mathrm{pH}$ decrease, the rate of nitrification (Shammas, 1986). It shows that $\mathrm{pH}$ does not affect the nitrification and denitrification processes in this research. It can, therefore, be concluded that there is no effect of $\mathrm{pH}$ on $\mathrm{N}_{2} \mathrm{O}$ production inside the reactors.

\subsection{Effect of oxygen on GHGs emission from sludge}

To examine the effect of oxygen on greenhouse gas emissions from the digestion sludge of the wastewater treatment plants, experiments were carried out under different levels of oxygen. Reactors were setup at $37{ }^{\circ} \mathrm{C}$ with $500 \mathrm{ml}$ of digestion sludge.

The rate of $\mathrm{CH}_{4}$ emission, $\mathrm{P}$-value and $\mathrm{R}^{2}$ form the digestion sludge thus obtained are given in Table 3. The amount of oxygen supplied to the sludge reactors, rate of $\mathrm{CH}_{4}$ emission, $\mathrm{P}$-value $\mathrm{R}^{2}$, 
and dry weight are shown in Table 3. It shows that $\mathrm{CH}_{4}$ production from dry weight digestion sludge was almost equal at different level of $\mathrm{O}_{2}$ concentration.

Table 3: Emission rate of methane and dry weight of sludge under different levels of oxygen on the sludge at $37^{\circ} \mathrm{C}$

\begin{tabular}{|l|c|c|c|c|c|}
\hline \multicolumn{1}{|c|}{ Activities } & $\begin{array}{c}\text { Amount of } \\
\text { oxygen } \\
(\mathrm{mg} / \mathrm{L})\end{array}$ & $\begin{array}{c}\mathrm{CH} 4 \\
\text { Emission } \\
(\mathrm{mg} / \mathrm{L} / \mathrm{d})\end{array}$ & $\mathrm{P}$-value & $\mathrm{R} 2$ & $\begin{array}{c}\text { CH4 production from dry } \\
\text { weight } \\
(\mathrm{mg} \text { CH4/gdw sludge })\end{array}$ \\
\hline Digestion sludge & 0 & 20.8 & 0.00844 & 0.89 & 32 \\
\hline Digestion sludge & 0.1 & 18.8 & 0.01978 & 0.96 & 28 \\
\hline Digestion sludge & 0.4 & 18.2 & 0.01874 & 0.81 & 29 \\
\hline Digestion sludge & 1.0 & 18.0 & 0.11994 & 0.81 & 26 \\
\hline Digestion sludge & 2.0 & 17.8 & 0.05311 & 0.83 & 25 \\
\hline
\end{tabular}

Fig. 8 shows the methane emission rate under different amounts $(0,0.1,0.4,1.0$, and $2.0 \mathrm{mg} / \mathrm{L})$ of oxygen supplied to the sample. It can be clearly seen from the figure that rate of methane emission decreases with increased amount of oxygen present in the sludge.

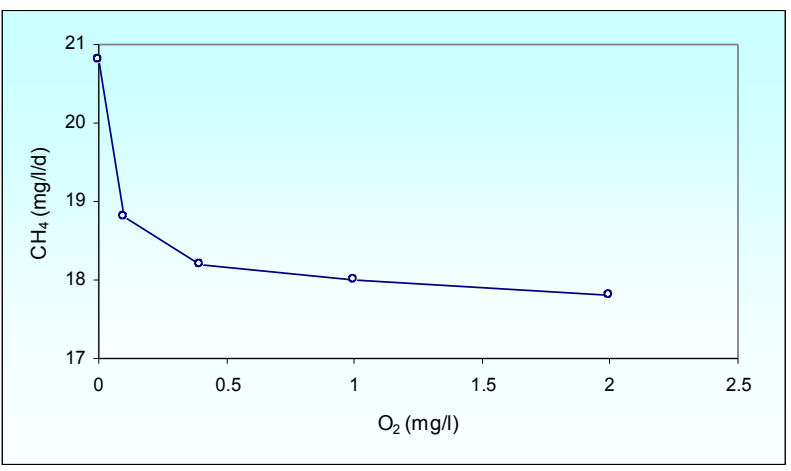

Figure 8: Methane production rate from different level of $\mathrm{O} 2$ at $37^{\circ} \mathrm{C}$

During the experiments, $\mathrm{CH}_{4}$ emitted from the reactor could be measured. However, $\mathrm{N}_{2} \mathrm{O}$ emission could not be detected. The measured $\mathrm{CH}_{4}$ from each experiment was plotted to examine the trend of emission and rate of emission in each level of oxygen supplied (Fig. 8). It was found that the production of $\mathrm{CH}_{4}$ started after 2 days and continued up to 25 days. These rates were $20.8,18.8,18.2,18.0$, and $17.8 \mathrm{mg} / \mathrm{L}$ per day respectively for the sludge samples with oxygen supply of $0,0.1,0.4,1.0$ and $2.0 \mathrm{mg} / \mathrm{L}$. It shows that higher the presence of oxygen in the sludge, lower the methane production from the sludge. This hypothesis is also supported from the total amount of $\mathrm{CH}_{4}$ produced from sludge samples. The total amounts of $\mathrm{CH}_{4}$ produced were respectively 580,571, 535, 495, and $505 \mathrm{mg} / \mathrm{L}$ from for $0,0.1,0.4,1.0$, and $2.0 \mathrm{mg} / \mathrm{L} \mathrm{of} \mathrm{O}_{2}$ supplied. Moller et al. (2004) also found that the total amount of methane production was less for the case where oxygen supplied was more. In terms of dry weight, methane production was 32 , 28, 29, 26, and $25 \mathrm{mg} \mathrm{CH}_{4}$ per gram of dw of sludge.

This research and that if the oxygen level is low in the sludge, the production of $\mathrm{CH}_{4}$ is high and vice versa. It is because of the fact that by lacking sufficient oxygen to consume the carbon content of the organic compound of the waste, anaerobes get rid of the excess carbon by 
combining with hydrogen thus resulting into more $\mathrm{CH}_{4}$. Wezernak et al. (1967) also pointed out that generation of methane takes place in the absence of oxygen, i.e., anaerobic decomposition of organic matter in the wastewater emits methane. Degradation of organic compounds to $\mathrm{CO}_{2}$ by aerobic decomposition and to $\mathrm{CH}_{4}$ and $\mathrm{CO}_{2}$ through anaerobic degradation will lead to emissions of $\mathrm{CH}_{4}$ and $\mathrm{CO}_{2}$ Moller et al., (2004) also support the experimental results of this study. Therefore, it concludes that rate of methane production is significantly affected with oxygen level and the relation is inverse.

\section{Conclusion}

Methane production was enhanced when there was glucose or nutrients or VFA in the sludge. If the sludge contains both nutrients $\left(\mathrm{NO}_{3}^{-}\right.$and $\left.\mathrm{NH}_{4}^{+}\right)$and VFA the rate of emission is further enhanced. Rate of methane production was more when the sludge temperature is high. It is due to fact that at higher temperature, microbial activities that affect methane emission increase. It is applicable for all sludge samples taken from different points of the treatment plant. The optimum temperature for methane production is higher than $37^{\circ} \mathrm{C}$. An inverse relationship was found between the rate of emission of methane and the concentration of oxygen in the sludge. Further, the presence of oxygen decelerated the rate of methane production. Rate of production was found highest for digestion sludge.

\section{Acknowledgements}

The author would like to express his profound gratitude to his supervisor Dr. Henk Lubberding for the help, and valuable suggestions. The author has earned valuable knowledge in term of technical and practical aspect from him during his study period in UNESCO-IHE, Institute for Water Education. The author takes this opportunity to express his heartfelt gratitude to his Prof. Dr. Piet Lens for his encouragement and valuable suggestions during the research work. The author thanks and appreciates to laboratory staffs for their sincere help and making the laboratory works interesting. Deepest sense of gratitude goes to his brother Dr. Laxmi Prasad Devkota for his encouragement and love, and for pushing the author up in this stage of education.

\section{REFERENCES}

[1] Cai M, Liu J and Wei Y. 2004. Enhance biohydrogen production from sewage sludge with alkaline pretreatment, Environmental Science and Technology. 38: 3195-3202

[2] Chen Y, Jiang S, Yuan H, Ahou Q and Gu G. 2006. Hydrolysis and acidification of waste activated sludge at different pH, Journal of Power Sources. 160: 897-902

[3] Gupta PK, Jha AK, Koul S, Sharma P, Pradan V, Gupta V, Sharma C, Singh N. 2006. Methane and Nitrous oxide emission from the bovine manure management practices in India. Environmental Pollution. 116: 219 -224.

[4] IPCC 2005. Annual Report (Available: http://yosemite.epa.gov/oar/globalwarming.nsf)

[5] Lay JJ, Li YY and Noike T. 1997. influences of $\mathrm{pH}$ and moisture contain on the methane production in high solid sludge digestion, Water Resources 31: 1518-1524

[6] Lin S. 2001. Water and Wastewater Calculation Manual, McGraw- Hill, New York, USA 
[7] Metcalf and Eddy. 2002. Wastewater Engineering: Collection and Pumping of wastewater, McGraw-Hill, New York USA

[8] Moller HB, Sommer SG and Ahirng BK 2004. Biological degradation and greenhouse gas emission during per storage of liquid animal manure, Journal Environmental quality. 33: 27-36

[9] Nitrification, Applied Microbiology. 15: 1211-1215

[10] Shammas NKH. 1986. Interactions of temperature $\mathrm{pH}$ and biomass on the nitrification process, Journal Water Pollution Control Federation. 56: 1036-1041

[11] Wezernak CT and Gannon JJ. 1967. Oxygen-Nitrogen Relationships in Autotrophic

[12] Zhu N, Krishankumar B, Zhao L, Sun L, Mizuochi M, Inamori Y. 2006. Effect of plant harvest on methane emission fro the two constructed wetlands designed for the treatment of wastewater, Journal of Environmental Management, in press (online available Dec. 2006, www.sciencedirect.com)

[13] Zinder SH, Anguish T, Cardell SC. 1984. Effects of Temperature on Methogenesis in a Thermophilic $\left(58^{\circ} \mathrm{C}\right)$ Anaerobic Digester, Applied and Environmental Microbiology. 47: 8080-813 